\title{
Assessing wind energy potential in Kurdistan province, Iran
}

\author{
Saeed Jahanbakhsh Asl • Majid Rezaei Banafsheh • \\ Yagob Dinpashoh • Marziyeh Esmaeilpour • \\ Kasra Mohammadi • Ali Mohammad Khorshiddoust
}

Received: 31 January 2014/ Accepted: 5 April 2014/Published online: 30 April 2014

(c) The Author(s) 2014. This article is published with open access at Springerlink.com

\begin{abstract}
In this study, 3-h wind speed data for years 1987-2009 at 10, 20 and $40 \mathrm{~m}$ heights have been analyzed for Kurdistan province. Wind energy potential at five stations in this province was investigated. Six types of methods, namely, graphical, empirical, method of moment, energy pattern factor, maximum likelihood and probabilityweighted moments were used to estimate the parameters. The results showed that MOM was an efficient method among others in the present study because it had the lowest value of the Chi-square statistics. Also, wind speed for $T$ year return period was estimated. In the annual time scale, the range of shape parameter, $k$, was between 0.78 and 1.03 whereas the range of the scale parameter, $c$, was between 1.84 and $4.37 \mathrm{~m} / \mathrm{s}$. Also, the most important characteristics of wind energy were evaluated. Among all the stations, Bijar and Zarineh Obato were found to be the best sites for wind energy harnessing. Bijar had the highest value of wind power density at $10 \mathrm{~m}$ height, which was equal to $308 \mathrm{~W} / \mathrm{m}^{2}$. In average, the rank of stations according to 100 years return period was as: (1) Zarineh Obato, (2) Bijar, (3) Ghorveh, (4) Saghez and (5) Sanandaj.
\end{abstract}

Keywords Iran · Kurdistan - Weibull distribution · Wind energy · Wind frequency

S. Jahanbakhsh Asl · M. Rezaei Banafsheh

M. Esmaeilpour $(\square) \cdot$ A. M. Khorshiddoust

Faculty of Geography and Planning, University of Tabriz,

29 Bahman Ave, Tabriz, Iran

e-mail: s.esmaeilpour@gmail.com

Y. Dinpashoh

Faculty of Water Engineering, University of Tabriz, Tabriz, Iran

K. Mohammadi

Mechanical Engineering Department, Kashan University,

Kashan, Iran

\section{List of symbols}

$c \quad$ Scale parameter of Weibull function $(\mathrm{m} / \mathrm{s})$

$E / A \quad$ Wind energy density

$f(U) \quad$ Probability density function

$F(U) \quad$ Cumulative distribution function

$k \quad$ Shape parameter of Weibull function, dimensionless

$P(U) \quad$ Power of wind speed (W)

$P / A \quad$ Wind power density $\left(\mathrm{w} / \mathrm{m}^{2}\right)$

$\rho^{*} \quad$ Power law exponent

$t^{*} \quad$ Time duration (h)

$T_{\mathrm{r}} \quad$ Return period (year)

$U \quad$ Wind speed $(\mathrm{m} / \mathrm{s})$

$\bar{U} \quad$ Mean wind speed $(\mathrm{m} / \mathrm{s})$

$U_{\text {max,E }} \quad$ Wind speed which carries maximum wind energy $(\mathrm{m} / \mathrm{s})$

$U_{\mathrm{mp}} \quad$ Most probable wind speed $(\mathrm{m} / \mathrm{s})$

$U_{\mathrm{Tr}} \quad$ Wind speed corresponding to $T_{\mathrm{r}}$ return period $(\mathrm{m} / \mathrm{s})$

$\operatorname{Var}(U) \quad$ Variance of wind speed $(\mathrm{m} / \mathrm{s})$

\section{Greek letters}

$\Gamma$ () Gamma function

$\rho \quad$ Air density $\left(\mathrm{kg} / \mathrm{m}^{3}\right)$

\section{Introduction}

The main sources of energy in Iran are fuel, oil and gas. Even though there are cheap renewable energy sources like wind energy, their use is limited. In recent decades, population growth has increased the energy demand and its consumption. On the other hand, increase of the use of fuel and gas causes atmospheric problems like air pollution and 
greenhouse effects. It seems that the use of renewable energies like wind instead of other fuels and gas may alleviate consequences of these problems. Hence, there is a need to select suitable places to install wind turbines.

Wind energy conservation systems which are used to generate electricity and water pumping by direct mechanical means are techno-economically feasible in different locations of Iran. There are few wind farms in Iran and most of them are located in the eastern and northern parts of the country. Iran's potential for wind power generation is estimated to be about 6,500 MW [1]. The contribution of wind energy for production of electricity is about $0.04 \%$. However, there are many other suitable locations, which seem to have a high potential for wind energy production. In Iran, due to low price of fuel and gas, energy is mainly generated using fossil fuel. Fossil fuel with $89.91 \%$ is the major supplier of electricity energy in Iran.

Wind speed frequency analysis is an important task in many fields of environmental studies including the selection of suitable places to generate electricity from wind power. Most of the investigators have used family of extremes value (EV) distributions for this purpose. This is due to the fact that EV distributions are recognized as a good candidate for analyzing wind speed data [2-5]. Among the extreme value distributions, the Weibull distribution is widely used to analyze wind speed data. For example, wind data analysis was conducted for five coastal stations of Saudi Arabia [6]. Katsoulis [7] assessed wind energy potential in Greece. He found different wind power densities in different parts of the country. In the eastern parts, especially on the Aegean Sea islands, the annual average of wind energy was $600 \mathrm{~W} / \mathrm{m}^{-2}$ which showed that these islands were possible locations for utilization of wind energy. Bensoussan et al. [8] investigated the wind energy on a yearly time scale. They showed a very good estimation of the mean wind speed using the Weibull distribution. Ucar and Balo [9] used Weibull and Rayleigh distributions for the investigation of wind energy potential in Kartalkaya in Turkey. The mean wind power density in the investigated location was $303 \mathrm{~W} / \mathrm{m}^{2}$.

Wind energy potential was studied in Karnataka, India [10]. Results showed that the average wind speed in Karnataka varied from $0.85 \mathrm{~m} / \mathrm{s}$ in Bagalkote to $8.28 \mathrm{~m} / \mathrm{s}$ in Chikkodi during the monsoon season. The northern zone of Karnataka with the highest wind velocity is ideally suited for installing wind farms. It was found that if $2 \%$ of the watersheds were used for harnessing wind energy, about $0.75-2 \mathrm{MW}$ could be generated at many locations.

Wind speed data of four stations in Island in Turkey were used to study wind energy potential [11]. Weibull distribution was used for frequency analysis of wind speed. Results showed that Weibull frequency reached at top point $7 \mathrm{~m} / \mathrm{s}$ with a value of 0.08 . For $14 \mathrm{~m} / \mathrm{s}$, the curve gave a frequency of about 0.04 ; it dropped to 0.02 at $18 \mathrm{~m} / \mathrm{s}$. They concluded that Weibull distribution fitted wind speed data reasonably. They showed that December and March were the 2 months in which the average wind speed was the highest throughout the year in Aydınıck. Uğurlu region had high frequencies if there were higher wind speeds and power in the studied area. Chellali et al. [12] used Weibull distribution for wind speed observation during the time period of 1 year (year 2007) at six airport meteorological stations in Algeria. They found that in Algeria the values of c varied between 4.29 and 7.15. Similarly, the values of $k$ varied between 1.69 and 2.45. Rehman et al. [13] used Weibull distribution for assessing wind resource in Saudi Arabia. They estimated the shape and scale parameters using maximum likelihood. They suggested the windiest sites for wind power development. Ajayi et al. [14] analyzed the electricity generation potential from wind at Kano, Nigeria. Monthly wind power ranged between 3.6 and $12.5 \mathrm{MWh} / \mathrm{m}^{2}$. They also concluded that wind speed at Kano might be economically viable for wind-to-electricity.

There are few studies on wind energy in different points of Iran. Type I extreme value distribution was used to analyze wind data frequency in Isfahan province, Iran [15]. It was found that hazardous wind events with low exceedance probability have rarely happened in the region.

Wind energy data were analyzed in Shahrbabak in Iran [4]. Authors used Weibull distribution and found that Weibull shape parameter, $k$, ranged from 1.72 to 1.93 and Weibull scale parameter, $c$, were in the range of 4.85-6.10 $(\mathrm{m} / \mathrm{s})$. They concluded that the cost of $1 \mathrm{~kW} \mathrm{~h}$ was about 18 cents (US cent, 2010) which was 5 cents higher than the market price.

Based on our best knowledge, there was no detailed study conducted on wind energy potential in Kurdistan province of Iran. Therefore, the main aim of this study was the analysis of wind energy potential in Kurdistan province, Iran.

\section{Methods}

Study area

The study area is Kurdistan province located in the west of Iran. This mountainous area lies approximately between $34^{\circ}, 44^{\prime} \mathrm{N}$ and $36^{\circ}, 30^{\prime} \mathrm{N}$ latitudes and $45^{\circ}, 31^{\prime} \mathrm{E}$ and $48^{\circ}$, $16^{\prime} \mathrm{E}$ longitudes. Based on the Koppen's climate classification, most portions of this area are categorized as D and $\mathrm{C}$ types. The arrangement of mountains in the studied area plays an essential role in wind speed and/or its direction. The mean regional annual precipitation is about $500 \mathrm{~mm}$ [16]. Furthermore, west of the area receives more rain in comparison to the east. Nearly $40 \%$ of the annual 


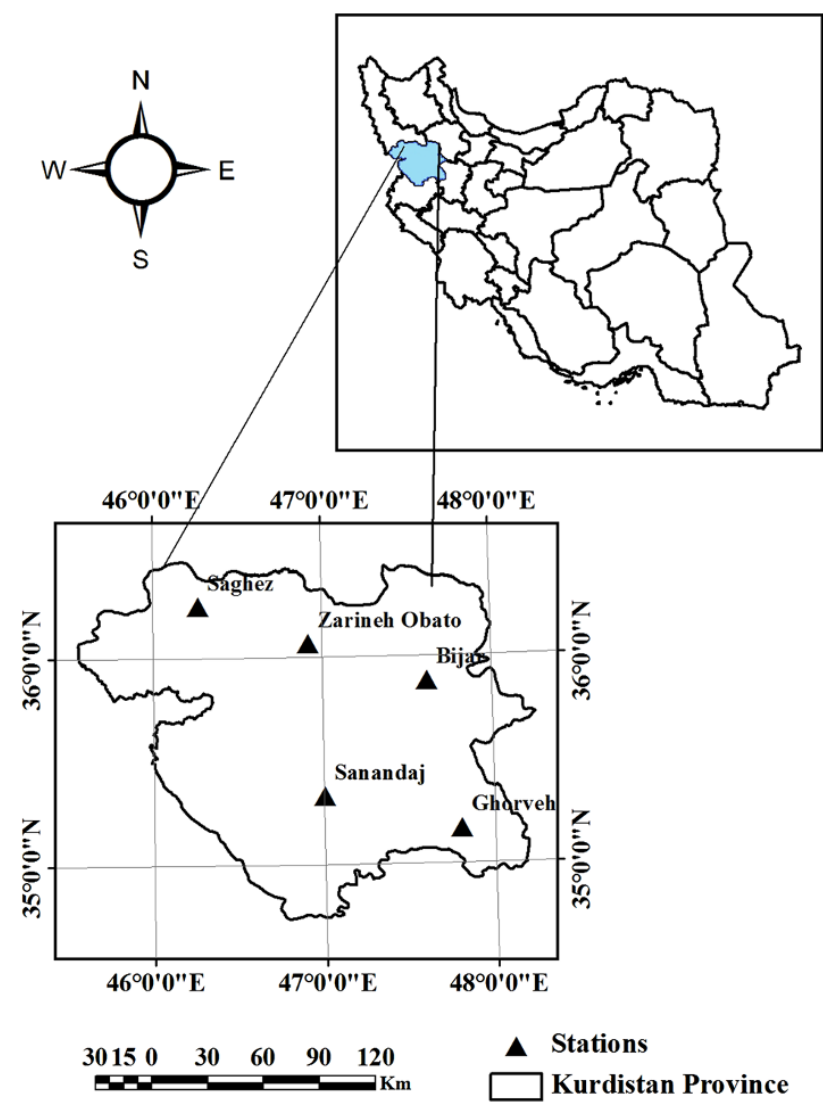

Fig. 1 Study area and location of stations

precipitation is received as snow in the winter (January, February and March). The mean annual reference crop evapotranspiration is estimated to be in the range of 1,100 and $1,300 \mathrm{~mm}$ [17]. Mean regional air temperature varies from $-1.7{ }^{\circ} \mathrm{C}$ in January to $25^{\circ} \mathrm{C}$ in July.

Station selection and data

Five stations, having sufficient wind speed records in three hour time intervals were selected for this study. Criteria for selection of sites were: (1) having sufficient hourly data, (2) lack of missing data up to $10 \%$ of total data, (3) having a reasonable density of sites on the studied area, (4) availability of data. Map of Kurdistan province with its different regions is shown in Fig. 1. Details of the selected stations are presented in Table 1.

Wind speed data observed at $10 \mathrm{~m}$ height and in 3-h time intervals were prepared in digital form from the Islamic Republic of Iran Meteorological Organization. Daily mean of wind speed data was calculated from the data. Few missing data were estimated using the linear regression method [18]. Quality of data was carefully controlled by plotting data time series and inspection for possible outliers. Few outliers existing in time series were substituted by their long-term reciprocal means.
Table 1 Details of the selected stations located in Kurdistan province, Iran

\begin{tabular}{lllll}
\hline Station & Latitude & Longitude & Altitude $(\mathrm{m})$ & Time period \\
\hline Saghez & $36^{\circ} 15^{\prime}$ & $46^{\circ} 16^{\prime}$ & $1,522.8$ & $1987-2009$ \\
Sanandaj & $35^{\circ} 20^{\prime}$ & $47^{\circ} 00^{\prime}$ & $1,373.4$ & $1987-2009$ \\
Bijar & $35^{\circ} 53^{\prime}$ & $47^{\circ} 37^{\prime}$ & $1,883.4$ & $1987-2009$ \\
Ghorveh & $35^{\circ} 10^{\prime}$ & $47^{\circ} 38^{\prime}$ & $1,906.0$ & $1989-2008$ \\
Zarineh Obato & $36^{\circ} 04^{\prime}$ & $46^{\circ} 55^{\prime}$ & $2,142.6$ & $1989-2009$ \\
\hline
\end{tabular}

Methodology

Wind frequency analysis and wind power density were conducted on wind speed data of each month and year at all selected stations. Analyses were carried out for three heights of 10, 20 and $40 \mathrm{~m}$ above the ground surface. The methods were described in the following subsections.

\section{Weibull probability distribution}

The mean wind speed, $\bar{U}$, and the standard deviation of wind speed were calculated after deriving the daily wind speed records, $U$. Weibull distribution was fitted for each of the monthly and annual time series, separately. This distribution has been used for frequency analysis of wind speed by many investigators [11, 19-22].

The general form of the Weibull probability density function, $f(U)$, is as follows:

$$
f(U)=\left(\frac{k}{c}\right)\left(\frac{U}{c}\right)^{k-1} \exp \left[-\left(\frac{U}{c}\right)^{k}\right] \quad U>0 ; \quad c, k>0 .
$$

The cumulative distribution function is written by:

$F(U)=1-\exp \left[-\left(\frac{U}{c}\right)^{k}\right]$

where $k$ and $c$ are the parameters, which should be estimated from the observations. To estimate the parameters, a number of methods have been proposed in the last decades. Three of them are discussed in detail in [23]. All the six methods used in the present study have not been checked by previous relevant studies for wind speeds in Iran. The used methods were:

1. Probability weighted moments

$$
\begin{aligned}
& a_{s}=\hat{a}_{s}=\hat{M}_{1,0, s}=\frac{1}{N} \sum_{i=1}^{N}\left(\begin{array}{r}
N-i \\
s
\end{array}\right) x_{i} /\left(\begin{array}{r}
N-1 \\
s
\end{array}\right) \\
& b_{r}=\hat{B}_{r}=\hat{M}_{1, r, 0}=\frac{1}{N} \sum_{i=1}^{N}\left(\begin{array}{r}
i-1 \\
r
\end{array}\right) x_{i} /\left(\begin{array}{r}
N-1 \\
r
\end{array}\right)
\end{aligned}
$$


where $N$ is the number of observations and $x_{i}$ is each data [23].

2. Graphical

The equation for this method can be represented by a double logarithmic transformation as follows:

$\ln \{-\ln [1-F(v)]\}=k \ln (v)-k \ln (c)$.

3. Empirical method

The empirical method is considered a special case of moment method. Where the Weibull parameters $k$ and $c$ are given by the equations shown below:

$k=\left(\frac{\sigma}{\bar{V}}\right)^{-1.0 .86}$

$\bar{v}=c \Gamma\left(1+\frac{1}{k}\right)$

4. Method of moment

The moment method can be used as an alternative to the maximum likelihood method and in this case, the parameters $k$ and $c$ are determined by the following equations:

$\bar{v}=c \Gamma\left(1+\frac{1}{k}\right)$

$\sigma=c \Gamma\left[\left(1+\frac{2}{k}\right)-\Gamma^{2}\left(1+\frac{1}{k}\right)\right]^{1 / 2}$

where $\bar{v}$ and $\sigma$ are the mean wind speed and the standard deviation of the observed data of wind speed, respectively. A written code in Maple software was used here to estimate the parameters.

5. Maximum likelihood

In this method, the parameters $k$ and $c$ are determined according to the equations below:

$k=\left[\frac{\sum_{i=1}^{n} v_{i}^{k} \ln \left(v_{i}\right)}{\sum_{i=1}^{n} v_{i}^{k}}-\frac{\sum_{i=1}^{n} \ln \left(v_{i}\right)}{n}\right]^{-1}$

$c=\left(\frac{1}{n} \sum_{i=1}^{n} v_{i}^{k}\right)^{\frac{1}{k}}$

where $n$ is the number of observations performed and $v_{i}$ is the wind speed measured at the interval $i$.

6. Energy pattern factor

$$
\begin{aligned}
& E_{\mathrm{pf}}=\frac{\bar{v}^{3}}{\left(\bar{v}^{3}\right)} \\
& K=1+\frac{3.69}{\left(E_{\mathrm{pf}}\right)^{2}} \\
& \bar{v}=c \Gamma\left(1+\frac{1}{k}\right)
\end{aligned}
$$

where $E_{\mathrm{pf}}$ is the energy pattern factor and $\Gamma$ is the gamma function defined by [24]:

$$
\Gamma(x)=\int_{0}^{\infty} t^{x-1} \exp (-t) \mathrm{d} t .
$$

Statistical analysis

$X^{2}=\sum_{j=1}^{k} \frac{\left(O_{j}-E_{j}\right)^{2}}{E_{j}}$

where $O_{j}$ is the observed number and $E_{j}$ is the expected value [23].

The quintiles of the Weibull distribution were derived from (17):

$U=c\left[\ln \left(\frac{1}{1-F}\right)\right]^{1 / k}$

where $F$ is the non-exceedance probability.

Although most of the hydrologic studies conducted the frequency analysis for hydrologic parameters, it seems that few studies use such analysis for wind speed, especially for Iran. In this study, we analyzed wind speed frequency. This analysis made the study to be different from others' work to some extent.

The relationship between the non-exceedance probability of events, $F$, and its corresponding return period, $T_{\mathrm{r}}$, can be written as [25]:

$T_{\mathrm{r}}=\frac{1}{1-F(u)}$

or

$F(u)=\frac{T_{\mathrm{r}}-1}{T_{\mathrm{r}}}$.

Substituting (18) in (17) yields:

$U_{\mathrm{Tr}}=c\left[\ln \left(T_{\mathrm{r}}\right)\right]^{\frac{1}{k}}$.

This can be used for prediction of wind speed for a given return period.

The mean and variance of the wind speed observations are [26]:

$\bar{U}=c \Gamma\left(1+\frac{1}{k}\right)$

$\operatorname{Var}(U)=c^{2}\left\{\Gamma\left(1+\frac{2}{k}\right)-\left[\Gamma\left(1+\frac{1}{k}\right)\right]^{2}\right\}$

where $\bar{U}$ and $\operatorname{Var}(U)$ are the mean and variance of the wind speed data, respectively. $c$ and $k$ are the scale and shape 
parameters, respectively. A lower shape factor, $k$, indicates a relatively wide distribution of wind speeds around the average, whereas a higher value for $k$ indicates a more sharper peak and narrow distribution of wind speeds (like tropical wind situations). A lower value of $\mathrm{k}$ will normally lead to a higher energy production for a given average wind speed. This is due to the fact that a wider distribution of wind speed increases the chance of obtaining higher wind speeds. Higher wind speeds in turn may produce large kinetic energy because it is a cubic function of wind speed.

\section{Weibull parameter variation with height}

The values of Weibull parameters (say $c_{a}$ and $k_{a}$ ) can be evaluated at any desired height $\left(z_{a}\right)$ in meter, based on the records at the standard anemometer height of $10 \mathrm{~m}$ using below equations [27]:

$k_{a}=k_{10}\left[1-0.0881 \ln \left(\frac{z_{a}}{10}\right)\right]^{-1}$

$c_{a}=\mathrm{c}_{10}\left(\frac{z_{a}}{10}\right)^{n}$

where $n$ is the power law exponent (coefficient) calculated from the below equation:

$n=\left[0.37-0.0881 \ln c_{10}\right]$.

In the present study, we used 20 and $40 \mathrm{~m}$ for $z_{a}$.

\section{Wind energy analysis}

Wind energy analysis was conducted as follows. Once the parameters of the distribution were estimated, the most probable wind speed, $U_{\mathrm{mp}}$, was obtained as [11]:

$U_{\mathrm{mp}}=c\left(1-\frac{1}{k}\right)^{1 / k}$

$U_{\mathrm{mp}}$ is undefined if $k$ was $<1$.

Furthermore, wind speed having the maximum energy, $U_{\text {max }, \mathrm{E}}$, represents wind speed which carries maximum wind energy being calculated:

$U_{\max , \mathrm{E}}=c\left(1+\frac{2}{k}\right)^{1 / k}$.

The power of the wind speed (in $\mathrm{W}), P(U)$, which flows at speed $U$ through a blade sweep area $A$, increases with the cubic of the wind speed and area as follows [4]:

$P(U)=\frac{1}{2} \rho A U^{3}$

where $\rho$ is the density of air assumed here to be a standard value of $1.2 \mathrm{~kg} / \mathrm{m}^{3}$. Wind power density (in $\mathrm{W} / \mathrm{m}^{2}$ ) at a station was calculated as follows:
$\frac{P}{A}=\int_{0}^{\infty} P(U) f(U) \mathrm{d} U=\frac{1}{2} \rho c^{3} \Gamma\left(\frac{k+3}{k}\right)$.

The wind energy density was also calculated from the following equation:

$\frac{E}{A}=\frac{1}{2} \rho c^{3} \Gamma\left(\frac{k+3}{k}\right) t^{*}$

where $t^{*}$ is the time duration, which is considered to be $720 \mathrm{~h}$ for the monthly durations.

\section{Results and discussion}

Calm wind percentage

Table 2 shows the calm wind percentages of different stations on the monthly, seasonal and annual time scales. As it can be inferred from Table 2, the calm wind prevails from $29.5 \%$ (at Bijar) to $59.6 \%$ (at Saghez) in the annual time scale. However, on the seasonal time scale it varies from $22.5 \%$ (in spring at Bijar) to about $64.9 \%$ (in autumn at Saghez). Moreover, in the monthly time scale this varies from $17.7 \%$ (at Bijar in April) to $67.4 \%$ (at Saghez in December). It can be concluded that the range of calm wind percentage becomes wider as time resolution becomes smaller. It was found that Saghez had the most calm wind condition among other stations, whereas Bijar was found to be the windiest station across the study area. Most of the stations experienced windy condition (less calm) in April and May.

\section{Average wind speed}

Table 3 shows the average wind speed in annual time scale. As it can be seen from Table 3, "Bijar" station has a better situation for wind energy harnessing among the others. This is due to the fact that under windy conditions, the average of wind speed at Baneh is $4.12 \mathrm{~m} / \mathrm{s}$, which is the highest among all selected stations.

Figure 2 shows the average of monthly wind speed for 10,20 and $40 \mathrm{~m}$ at Bijar. In the monthly time scale, April is the windiest month in Kurdistan province.

It can be concluded that the average of monthly wind speed at $10 \mathrm{~m}$ height of Bijar has varied from $3.34 \mathrm{~m} / \mathrm{s}$ at January to $5.64 \mathrm{~m} / \mathrm{s}$ at April. Mean wind speed seems to be constant from July to January (Fig. 2).

Köse [28] reported that in Kütahya, Turkey, the measured average wind speed for a period of 20 months was $4.62 \mathrm{~m} / \mathrm{s}$ at the height of $30 \mathrm{~m}$. 
Table 2 Percent of calm wind in the selected stations in the study area

\begin{tabular}{lccccccccccccccccc}
\hline Station & Jan & Feb & Mar & Apr & May & Jun & July & Aug & Sep & Oct & Nov & Dec & Winter & Spring & Summer & Autumn & Annual \\
\hline Saghez & 66.4 & 58.8 & 51.5 & 48.3 & 55.7 & 59.7 & 57.2 & 59.6 & 62.7 & 61.1 & 66.2 & 67.4 & 58.9 & 54.6 & 59.8 & 64.9 & 59.6 \\
Sanadaj & 63.8 & 54.6 & 50.2 & 50.4 & 52.3 & 51.4 & 44.0 & 50.5 & 59.3 & 60.2 & 65.0 & 64.4 & 56.3 & 51.4 & 51.2 & 63.2 & 55.5 \\
Zarineh & 49.7 & 42.7 & 35.7 & 28.0 & 31.0 & 35.1 & 39.0 & 39.2 & 36.0 & 39.7 & 45.4 & 47.8 & 42.7 & 31.4 & 38.1 & 44.3 & 39.1 \\
Bijar & 43.1 & 33.3 & 23.7 & 17.7 & 24.0 & 25.8 & 27.3 & 31.9 & 30.6 & 29.3 & 32.8 & 35.1 & 33.1 & 22.5 & 29.9 & 32.4 & 29.5 \\
Ghorveh & 54.3 & 44.6 & 33.8 & 28.9 & 31.6 & 36.5 & 37.5 & 38.1 & 42.7 & 44.1 & 50.5 & 50.7 & 44.1 & 32.3 & 39.4 & 48.4 & 41.0
\end{tabular}

Table 3 Mean annual wind speed for the selected stations in the Kurdistan province $(\mathrm{m} / \mathrm{s})$

\begin{tabular}{llll}
\hline & \multicolumn{3}{l}{ Height } \\
\cline { 2 - 4 } Station & $10 \mathrm{~m}$ & $20 \mathrm{~m}$ & $40 \mathrm{~m}$ \\
\hline Bijar & 4.12 & 4.77 & 5.56 \\
Saghez & 2.29 & 2.74 & 3.24 \\
Sanandaj & 2.07 & 2.47 & 2.95 \\
Ghorveh & 3.24 & 3.78 & 4.44 \\
Zarineh & 3.70 & 4.30 & 5.04 \\
Obato & & & \\
\hline
\end{tabular}

Wind speed distribution

It was observed that method of moment was the best method for estimating scale and shape parameters of Weibull distribution because it had the lowest value of Chisquare. Hence, it was used for wind energy potential assessment.

Table 4 shows the Weibull parameters $(k$ and $c$ ) for Bijar station obtained from six methods. For the purpose of brevity, the Weibull parameters of other stations are not provided here. Akpinar and Akpinar [29] reported that a mean value of $k$ is 1.6 in Maden-Elazig, Turkey. They reported that the mean value of $c$ was 5.83 for the same station. It is worthy to mention that wind speed frequency analysis is only valid for a given station and a given month because wind is a local climatic parameter and its speed and direction change from point to point and month to month. So caution should be used in using the obtained results for other neighbor stations. Also, it is important to use $c$ and $k$ values in predicting return period of wind speed for a given month.

As mentioned earlier, the parameters of the Weibull distribution were used to estimate the most probable wind speed, $U_{\mathrm{mp}}$, wind speed which carries maximum wind energy, $U_{\max , \mathrm{E}}$, wind power density, $\frac{P}{A}$ and wind energy density, $\frac{E}{A}$.

\section{Most probable wind speed}

The most probable wind speed, $U_{\mathrm{mp}}$, was calculated for the selected stations at 10,20 and $40 \mathrm{~m}$ heights. At annual time scale, the highest $U_{\mathrm{mp}}$ was found to be about $1.89 \mathrm{~m} / \mathrm{s}$ at $10 \mathrm{~m}$ height at Bijar. This was $2.99 \mathrm{~m} / \mathrm{s}$ at $20 \mathrm{~m}$ height and $4.39 \mathrm{~m} / \mathrm{s}$ at $40 \mathrm{~m}$ height for the same station. Table 5 shows the values of $U_{\mathrm{mp}}$ at the monthly time scale for the five selected sites. It was found that most of the stations had a high value of $U_{\mathrm{mp}}$ in April. In contrast, the month having the lowest value of $U_{\mathrm{mp}}$ varied from site to site. The highest value of $U_{\mathrm{mp}}$ at $10 \mathrm{~m}$ was $5.17 \mathrm{~m} / \mathrm{s}$ in April at Bijar. This was $6.72 \mathrm{~m} / \mathrm{s}$ at $20 \mathrm{~m}$ height and $8.56 \mathrm{~m} / \mathrm{s}$ at $40 \mathrm{~m}$ height. However, the lowest value of $U_{\mathrm{mp}}$ at $10 \mathrm{~m}$ was about $0.16 \mathrm{~m} / \mathrm{s}$ experienced in September at Ghorveh.

It is worthy to mention that in some time series the estimated parameter of $k$ was less than unity. In such a condition, the $U_{\mathrm{mp}}$ was assumed to be negligible. Therefore, it can be concluded that the two sites, namely Saghez
Fig. 2 The monthly mean wind speed for three heights of Bijar station

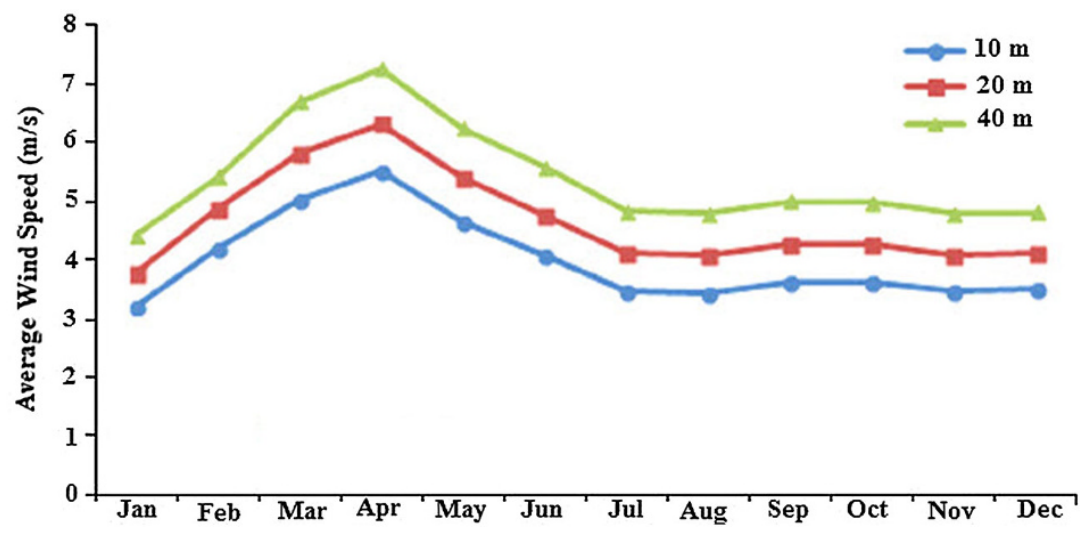


Table 4 Weibull parameters $(k, c)$ obtained from six methods at Bijar station

\begin{tabular}{|c|c|c|c|c|c|c|c|c|c|c|c|c|c|c|}
\hline Method & Weibull parameters & Jan & Feb & Mar & Apr & May & June & July & Aug & Sep & Oct & Nov & Dec & Ann. \\
\hline \multirow[t]{2}{*}{ Graphical } & $k$ & 0.48 & 0.54 & 0.64 & 0.72 & 0.65 & 0.63 & 0.63 & 0.59 & 0.60 & 0.56 & 0.54 & 0.52 & 0.59 \\
\hline & $c$ & 5.29 & 4.16 & 5.87 & 6.89 & 5.45 & 4.78 & 3.96 & 3.77 & 4.02 & 3.79 & 3.33 & 3.31 & 4.55 \\
\hline \multirow[t]{2}{*}{ Empirical } & $k$ & 0.89 & 1.10 & 1.33 & 1.47 & 1.31 & 1.36 & 1.32 & 1.24 & 1.27 & 1.16 & 1.04 & 1.05 & 1.21 \\
\hline & $c$ & 3.18 & 4.50 & 5.63 & 6.24 & 5.20 & 4.61 & 3.92 & 3.84 & 4.04 & 3.96 & 3.68 & 3.72 & 4.38 \\
\hline \multirow[t]{2}{*}{ MOM } & $k$ & 0.90 & 1.09 & 1.31 & 1.45 & 1.29 & 1.35 & 1.31 & 1.23 & 1.26 & 1.15 & 1.04 & 1.05 & 1.20 \\
\hline & $c$ & 3.19 & 4.49 & 5.62 & 6.23 & 5.19 & 4.59 & 3.91 & 3.83 & 4.03 & 3.95 & 3.67 & 3.71 & 4.37 \\
\hline \multirow[t]{2}{*}{ MLM } & $k$ & 0.64 & 0.77 & 0.99 & 1.17 & 1 & 0.99 & 0.95 & 0.88 & 0.91 & 0.83 & 0.75 & 0.73 & 0.88 \\
\hline & $c$ & 2.56 & 3.86 & 5.16 & 5.89 & 4.8 & 4.21 & 3.55 & 3.42 & 3.62 & 3.47 & 3.14 & 3.13 & 3.90 \\
\hline \multirow[t]{2}{*}{ PWM } & $k$ & 0.70 & 1.08 & 1.49 & 1.75 & 1.38 & 1.23 & 1.02 & 0.98 & 1.04 & 0.99 & 0.87 & 0.88 & 1.12 \\
\hline & $c$ & 2.64 & 3.25 & 3.68 & 3.89 & 3.41 & 2.98 & 2.57 & 2.60 & 2.70 & 2.76 & 2.74 & 2.75 & 3 \\
\hline \multirow[t]{2}{*}{ EPF } & $k$ & 1.09 & 1.20 & 1.37 & 1.46 & 1.33 & 1.41 & 1.39 & 1.32 & 1.34 & 1.24 & 1.16 & 1.17 & 1.29 \\
\hline & $c$ & 3.46 & 4.62 & 5.66 & 6.23 & 5.22 & 4.63 & 3.95 & 3.89 & 4.08 & 4.03 & 3.81 & 3.84 & 4.45 \\
\hline
\end{tabular}

$k$ is dimensionless and the unit of $c$ is $\mathrm{m} / \mathrm{s}$

Table 5 The monthly $U_{\mathrm{mp}}$ values of the five selected stations

\begin{tabular}{|c|c|c|c|c|c|c|c|c|c|c|c|c|c|c|c|}
\hline & \multicolumn{3}{|l|}{ Bijar } & \multicolumn{3}{|c|}{ Ghorveh } & \multicolumn{3}{|c|}{ Saghez } & \multicolumn{3}{|c|}{ Sanandaj } & \multicolumn{3}{|c|}{ Zarineh Obato } \\
\hline & $10 \mathrm{~m}$ & $20 \mathrm{~m}$ & $40 \mathrm{~m}$ & $10 \mathrm{~m}$ & $20 \mathrm{~m}$ & $40 \mathrm{~m}$ & $10 \mathrm{~m}$ & $20 \mathrm{~m}$ & $40 \mathrm{~m}$ & $10 \mathrm{~m}$ & $20 \mathrm{~m}$ & $40 \mathrm{~m}$ & $10 \mathrm{~m}$ & $20 \mathrm{~m}$ & $40 \mathrm{~m}$ \\
\hline Jan & - & - & 0.34 & - & - & - & - & - & - & - & - & - & - & - & - \\
\hline $\mathrm{Feb}$ & 0.94 & 1.93 & 3.27 & - & - & - & - & - & - & - & - & - & - & - & 0.49 \\
\hline Mar & 3.62 & 5.02 & 6.74 & 0.86 & 1.76 & 2.99 & - & - & - & - & - & - & 0.52 & 1.40 & 2.64 \\
\hline Apr & 5.17 & 6.72 & 8.56 & 2.34 & 3.54 & 5.04 & - & - & 0.36 & - & - & - & 2.31 & 3.59 & 5.19 \\
\hline May & 3.13 & 4.44 & 6.06 & 1.24 & 2.20 & 3.47 & - & - & - & - & - & - & 1.34 & 2.39 & 3.76 \\
\hline Jun & 3.18 & 4.40 & 5.90 & 1.16 & 2.02 & 3.18 & - & - & - & - & - & - & 1.19 & 2.14 & 3.40 \\
\hline Jul & 2.47 & 3.53 & 4.86 & 1.17 & 2 & 3.12 & - & - & - & 0.16 & 0.65 & 1.41 & 0.95 & 1.80 & 2.95 \\
\hline Aug & 1.90 & 2.90 & 4.18 & 0.95 & 1.73 & 2.79 & - & - & - & - & - & 0.27 & 0.78 & 1.61 & 2.73 \\
\hline Sep & 2.20 & 3.26 & 4.60 & 0.16 & 0.74 & 1.63 & - & - & - & - & - & - & 0.91 & 1.78 & 2.96 \\
\hline Oct & 1.34 & 2.30 & 3.56 & - & 0.13 & 0.84 & - & - & - & - & - & - & - & 0.40 & 1.31 \\
\hline Nov & 0.34 & 1.07 & 2.14 & - & - & - & - & - & - & - & - & - & - & - & 0.50 \\
\hline Dec & 0.42 & 1.19 & 2.28 & - & - & - & - & - & - & - & - & - & - & - & 0.22 \\
\hline Ann. & 1.89 & 2.99 & 4.39 & 0.06 & 0.68 & 1.54 & - & - & - & - & - & - & 0.24 & 0.98 & 1.98 \\
\hline
\end{tabular}

and Sanandaj were not good sites for installing the wind turbines.

Wind speed which carries maximum energy

The wind speed which carries maximum energy, $U_{\max , \mathrm{E}}$, was calculated for the five selected stations at 10, 20 and $40 \mathrm{~m}$ heights. In annual time scale, the range of $U_{\max , \mathrm{E}}$ at $10 \mathrm{~m}$ height was between 8.18 and $10.79 \mathrm{~m} / \mathrm{s}$. Table 6 shows the $U_{\max , \mathrm{E}}$ for the selected stations. As it can be seen from Table 6 , the highest values of $U_{\text {max,E }}$ for all the sites were observed during late winter and early spring, when Mediterranean rainy systems come to Iran from the west. The highest value of $U_{\max , \mathrm{E}}$ at $10 \mathrm{~m}$ was about $12.75 \mathrm{~m} / \mathrm{s}$ observed in April at Bijar and it was 14.14 and $15.71 \mathrm{~m} / \mathrm{s}$ at 20 and $40 \mathrm{~m}$ (Table 6).
Wind power density $(P / A)$

The wind power density, $P / A$, was calculated for the five selected sites at three different heights. In annual time scale, highest value of $P / A$ at $10 \mathrm{~m}$ height was found to be about $170 \mathrm{~W} / \mathrm{m}^{2}$, which was observed at Zarineh Obato. It was $229.21 \mathrm{~W} / \mathrm{m}^{2}$ for $20 \mathrm{~m}$ height and $322.45 \mathrm{~W} / \mathrm{m}^{2}$ for $40 \mathrm{~m}$ height. Table 7 shows the $P / A$ values of the sites at three different heights. There is a slight difference between Bijar and Zarineh Obato station.

As it can be inferred from Table 7 , the value of $P / A$ varied largely among stations. It was found that the highest values of $P / A$ mainly were observed in April for most of the stations. The highest value of $P / A$ at $10 \mathrm{~m}$ height was found to be $308 \mathrm{~W} / \mathrm{m}^{2}$, which was observed in April at Bijar. It was 424 and $586 \mathrm{~W} / \mathrm{m}^{2}$ at 20 and $40 \mathrm{~m}$ heights, 
Table 6 The monthly $U_{\text {max,E }}$ values of the five selected stations

\begin{tabular}{|c|c|c|c|c|c|c|c|c|c|c|c|c|c|c|c|}
\hline & \multicolumn{3}{|l|}{ Bijar } & \multicolumn{3}{|c|}{ Ghorveh } & \multicolumn{3}{|c|}{ Saghez } & \multicolumn{3}{|c|}{ Sanandaj } & \multicolumn{3}{|c|}{ Zarineh Obato } \\
\hline & $10 \mathrm{~m}$ & $20 \mathrm{~m}$ & $40 \mathrm{~m}$ & $10 \mathrm{~m}$ & $20 \mathrm{~m}$ & $40 \mathrm{~m}$ & $10 \mathrm{~m}$ & $20 \mathrm{~m}$ & $40 \mathrm{~m}$ & $10 \mathrm{~m}$ & $20 \mathrm{~m}$ & $40 \mathrm{~m}$ & $10 \mathrm{~m}$ & $20 \mathrm{~m}$ & $40 \mathrm{~m}$ \\
\hline Jan & 11.1 & 12.1 & 13.26 & 10.51 & 11.29 & 12.21 & 8.32 & 8.96 & 9.72 & 7.68 & 8.34 & 9.13 & 10.92 & 11.82 & 12.87 \\
\hline Feb & 11.97 & 13.13 & 14.47 & 11.30 & 12.23 & 13.32 & 9.19 & 9.94 & 10.82 & 8.52 & 9.30 & 10.22 & 12.57 & 13.58 & 14.75 \\
\hline Mar & 12.38 & 13.70 & 15.20 & 10.72 & 11.84 & 13.14 & 10.14 & 11.05 & 12.11 & 9.08 & 9.94 & 10.93 & 12.08 & 13.21 & 14.52 \\
\hline Apr & 12.75 & 14.14 & 15.71 & 11.18 & 12.41 & 13.81 & 10.46 & 11.42 & 12.53 & 9.31 & 10.18 & 11.19 & 12.64 & 13.91 & 15.35 \\
\hline May & 11.63 & 12.91 & 14.36 & 10.29 & 11.42 & 12.73 & 9.75 & 10.60 & 11.60 & 8.64 & 9.48 & 10.45 & 11.42 & 12.60 & 13.95 \\
\hline Jun & 9.94 & 11.15 & 12.56 & 8.96 & 10.03 & 11.28 & 9.19 & 10.01 & 10.97 & 8.14 & 8.99 & 9.99 & 10.25 & 11.38 & 12.69 \\
\hline Jul & 8.66 & 9.79 & 11.10 & 8.38 & 9.43 & 10.66 & 8.71 & 9.57 & 10.59 & 7.07 & 7.98 & 9.05 & 9.42 & 10.51 & 11.77 \\
\hline Aug & 8.98 & 10.10 & 11.39 & 8.23 & 9.26 & 10.46 & 9.05 & 9.87 & 10.84 & 7.13 & 7.98 & 8.96 & 9.60 & 10.68 & 11.93 \\
\hline Sep & 9.24 & 10.39 & 11.72 & 8.81 & 9.81 & 10.97 & 9.28 & 10.04 & 10.95 & 7.64 & 8.38 & 9.26 & 9.92 & 11.03 & 12.30 \\
\hline Oct & 9.90 & 11.03 & 12.33 & 9.28 & 10.25 & 11.37 & 9.53 & 10.28 & 11.16 & 8.08 & 8.77 & 9.60 & 10.82 & 11.86 & 13.06 \\
\hline Nov & 10.41 & 11.49 & 12.73 & 10.27 & 11.14 & 12.15 & 9.32 & 10 & 10.80 & 8.44 & 9.08 & 9.84 & 10.39 & 11.36 & 12.49 \\
\hline Dec & 10.38 & 11.47 & 12.72 & 9.72 & 10.58 & 11.59 & 8.55 & 9.21 & 9.99 & 8.02 & 8.68 & 9.45 & 10.18 & 11.12 & 12.22 \\
\hline Ann. & 10.51 & 11.64 & 12.99 & 9.58 & 10.53 & 11.74 & 9.40 & 10.22 & 11.05 & 8.18 & 8.80 & 6.69 & 10.79 & 11.80 & 13.13 \\
\hline
\end{tabular}

Table 7 The monthly $P / A$ values in $\mathrm{W} / \mathrm{m}^{2}$ of the five selected stations

\begin{tabular}{|c|c|c|c|c|c|c|c|c|c|c|c|c|c|c|c|}
\hline & \multicolumn{3}{|l|}{ Bijar } & \multicolumn{3}{|c|}{ Ghorveh } & \multicolumn{3}{|l|}{ Saghez } & \multicolumn{3}{|c|}{ Sanandaj } & \multicolumn{3}{|c|}{ Zarineh Obato } \\
\hline & $10 \mathrm{~m}$ & $20 \mathrm{~m}$ & $40 \mathrm{~m}$ & $10 \mathrm{~m}$ & $20 \mathrm{~m}$ & $40 \mathrm{~m}$ & $10 \mathrm{~m}$ & $20 \mathrm{~m}$ & $40 \mathrm{~m}$ & $10 \mathrm{~m}$ & $20 \mathrm{~m}$ & $40 \mathrm{~m}$ & $10 \mathrm{~m}$ & $20 \mathrm{~m}$ & $40 \mathrm{~m}$ \\
\hline Jan & 174.57 & 233.72 & 316.45 & 125.02 & 165.38 & 221.79 & 53.52 & 72.62 & 100.10 & 44.50 & 61.67 & 86.75 & 155.23 & 206.74 & 278.73 \\
\hline Feb & 238.53 & 322.30 & 439.46 & 175.48 & 232.96 & 312.94 & 81.83 & 110.59 & 151.57 & 68.92 & 95.12 & 133.04 & 251.76 & 330.10 & 437.66 \\
\hline Mar & 278.65 & 381.46 & 526 & 171.37 & 236.33 & 328.86 & 126.90 & 171.91 & 235.66 & 88.75 & 122.12 & 170.13 & 241.34 & 324.21 & 439.66 \\
\hline Apr & 308.66 & 424.09 & 586.45 & 202.09 & 279.94 & 390.86 & 144.44 & 195.75 & 267.28 & 96.50 & 132.40 & 183.86 & 290.25 & 392.22 & 534.31 \\
\hline May & 229.94 & 317.83 & 442.57 & 153.66 & 214.39 & 301.72 & 107.76 & 145.94 & 200.16 & 75.99 & 105.45 & 148.14 & 210.29 & 287.73 & 397.12 \\
\hline Jun & 144.61 & 206.59 & 297.21 & 101.72 & 145.69 & 210.46 & 88.71 & 121.18 & 167.67 & 65.78 & 92.81 & 132.49 & 151.91 & 211.99 & 298.41 \\
\hline Jul & 95.30 & 139.21 & 204.85 & 83.66 & 121.40 & 177.66 & 80.20 & 111.68 & 157.37 & 47.98 & 70.90 & 105.79 & 117.48 & 166.23 & 237.29 \\
\hline Aug & 104.67 & 150.97 & 219.46 & 78.52 & 114.07 & 167.15 & 85.33 & 117.05 & 162.61 & 45.88 & 66.71 & 98.08 & 123.37 & 173.62 & 246.54 \\
\hline Sep & 114.86 & 165.15 & 239.30 & 92.40 & 131.08 & 187.77 & 86.05 & 116.46 & 159.77 & 49.03 & 68.93 & 98.21 & 136.71 & 191.44 & 270.47 \\
\hline Oct & 137.76 & 193.83 & 275.04 & 104.17 & 145.15 & 204.41 & 91.03 & 122.23 & 166.43 & 53.42 & 73.61 & 102.90 & 167.54 & 227.67 & 312.59 \\
\hline Nov & 153.78 & 211.98 & 295.03 & 126.73 & 170.23 & 231.52 & 78.05 & 104.15 & 141.12 & 55.64 & 75.26 & 103.42 & 142.65 & 193.89 & 266.44 \\
\hline Dec & 153.30 & 211.66 & 295 & 107.88 & 146.44 & 201.26 & 59.33 & 80.30 & 110.36 & 49.27 & 67.50 & 93.90 & 131.99 & 179.48 & 246.84 \\
\hline Ann. & 166.40 & 230.18 & 323.56 & 117.97 & 161.44 & 229.39 & 91.61 & 124.99 & 167.46 & 61.99 & 82.46 & 115.52 & 170.29 & 229.21 & 322.45 \\
\hline
\end{tabular}

respectively. In contrast, the lowest value of $P / A$ at $10 \mathrm{~m}$ height was found to be $44 \mathrm{~W} / \mathrm{m}^{2}$, which was observed at Sanandaj. It was $61 \mathrm{~W} / \mathrm{m}^{2}$ at $20 \mathrm{~m}$ and $86 \mathrm{~W} / \mathrm{m}^{2}$ at $40 \mathrm{~m}$ heights. Some sample qualitative magnitude evaluations of the wind resource are [3]:

$P / A<100 \mathrm{~W} / \mathrm{m}^{2}$ (poor)

$P / A \approx 400 \mathrm{~W} / \mathrm{m}^{2}$ (good)

$P / A>700 \mathrm{~W} / \mathrm{m}^{2}$ (great).

From the above criteria, it was found that Zarineh Obato and Bijar had a relatively good situation with respect to wind power density. This was true for all three selected heights.
Wind energy density $(E / A)$

The wind energy density, E/A, was calculated for all five selected stations, in three different heights and two time scales. In annual time scale, the highest value of $E / A$ at $10 \mathrm{~m}$ height was about $122.61 \mathrm{kWh} / \mathrm{m}^{2}$. It was $165 \mathrm{kWh} /$ $\mathrm{m}^{2} /$ month at $20 \mathrm{~m}$ height and $232 \mathrm{kWh} / \mathrm{m}^{2} /$ month at $40 \mathrm{~m}$ height. Table 8 shows the $E / A$ values for the selected sites. There is a slight difference between Bijar and Zarineh Obato in the annual time scale.

The highest value of $E / A$ belonged to Bijar station having E/A at 10 and $20 \mathrm{~m}$ height equal to 222 and $305 \mathrm{kWh} / \mathrm{m}^{2} /$ month, respectively. At $40 \mathrm{~m}$ height, it was 
Table 8 The monthly E/A values of the five selected stations

\begin{tabular}{|c|c|c|c|c|c|c|c|c|c|c|c|c|c|c|c|}
\hline & \multicolumn{3}{|l|}{ Bijar } & \multicolumn{3}{|l|}{ Ghorveh } & \multicolumn{3}{|l|}{ Saghez } & \multicolumn{3}{|c|}{ Sanandaj } & \multicolumn{3}{|c|}{ Zarineh Obato } \\
\hline & $10 \mathrm{~m}$ & $20 \mathrm{~m}$ & $40 \mathrm{~m}$ & $10 \mathrm{~m}$ & $20 \mathrm{~m}$ & $40 \mathrm{~m}$ & $10 \mathrm{~m}$ & $20 \mathrm{~m}$ & $40 \mathrm{~m}$ & $10 \mathrm{~m}$ & $20 \mathrm{~m}$ & $40 \mathrm{~m}$ & $10 \mathrm{~m}$ & $20 \mathrm{~m}$ & $40 \mathrm{~m}$ \\
\hline an & 125.69 & 168.28 & 227.85 & 90.02 & 119.08 & 159.69 & 38.54 & 52.29 & 72.07 & 32.04 & 44.40 & 62.46 & 111.76 & 148.85 & 200.69 \\
\hline Feb & 171.74 & 232.06 & 316.41 & 126.35 & 167.73 & 225.32 & 58.92 & 79.63 & 109.13 & 49.62 & 68.49 & 95.79 & 181.26 & 237.67 & 315.12 \\
\hline Mar & 200.62 & 274.65 & 378 & 123.38 & 170.15 & 236.78 & 91.37 & 123.78 & 169.67 & 63.90 & 87.93 & 122.50 & 173.77 & 233.43 & 316.55 \\
\hline Apr & 222.23 & 305.34 & 422.24 & 145.50 & 201.56 & 281.42 & 104 & 140.94 & 192.44 & 69.48 & 95.32 & 132.37 & 208.98 & 282.40 & 384.71 \\
\hline May & 165.56 & 228.83 & 318.65 & 110.64 & 154.36 & 217.23 & 77.58 & 105.07 & 144.11 & 54.71 & 75.92 & 106.66 & 151.41 & 207.17 & 285.92 \\
\hline Jun & 104.12 & 148.74 & 213.99 & 73.24 & 104.90 & 151.53 & 63.87 & 87.25 & 120.72 & 47.36 & 66.82 & 95.39 & 109.37 & 152.63 & 214.85 \\
\hline Jul & 68.61 & 100.23 & 147.49 & 60.23 & 87.40 & 127.91 & 57.74 & 80.41 & 113.30 & 34.54 & 51.05 & 76.17 & 84.58 & 119.69 & 170.85 \\
\hline Aug & 75.36 & 108.70 & 158.01 & 56.53 & 82.13 & 120.35 & 61.44 & 84.28 & 117.08 & 33.04 & 48.03 & 70.62 & 88.83 & 125.01 & 177.51 \\
\hline Sep & 82.70 & 118.91 & 172.29 & 66.53 & 94.37 & 135.19 & 61.96 & 83.85 & 115.04 & 35.30 & 49.63 & 70.71 & 98.43 & 137.83 & 194.73 \\
\hline Oct & 99.19 & 139.56 & 198.03 & 75 & 104.51 & 147.17 & 65.54 & 88 & 119.83 & 38.46 & 53 & 74.09 & 120.63 & 163.92 & 225.06 \\
\hline Nov & 110.72 & 152.63 & 212.42 & 91.24 & 122.56 & 166.69 & 56.19 & 74.99 & 101.61 & 40.06 & 54.19 & 74.46 & 102.71 & 139.60 & 191.84 \\
\hline Dec & 110.38 & 152.39 & 212.40 & 77.67 & 105.43 & 144.91 & 42.72 & 57.81 & 79.46 & 35.47 & 48.60 & 67.61 & 95.03 & 129.22 & 177.72 \\
\hline Ann. & 119.81 & 165.73 & 232.96 & 84.94 & 116.24 & 165.16 & 65.96 & 89.99 & 120.57 & 44.63 & 59.37 & 83.17 & 122.61 & 165.03 & 232.16 \\
\hline
\end{tabular}

Fig. 3 The wind speed at $10 \mathrm{~m}$ height according to the 100 -year return period

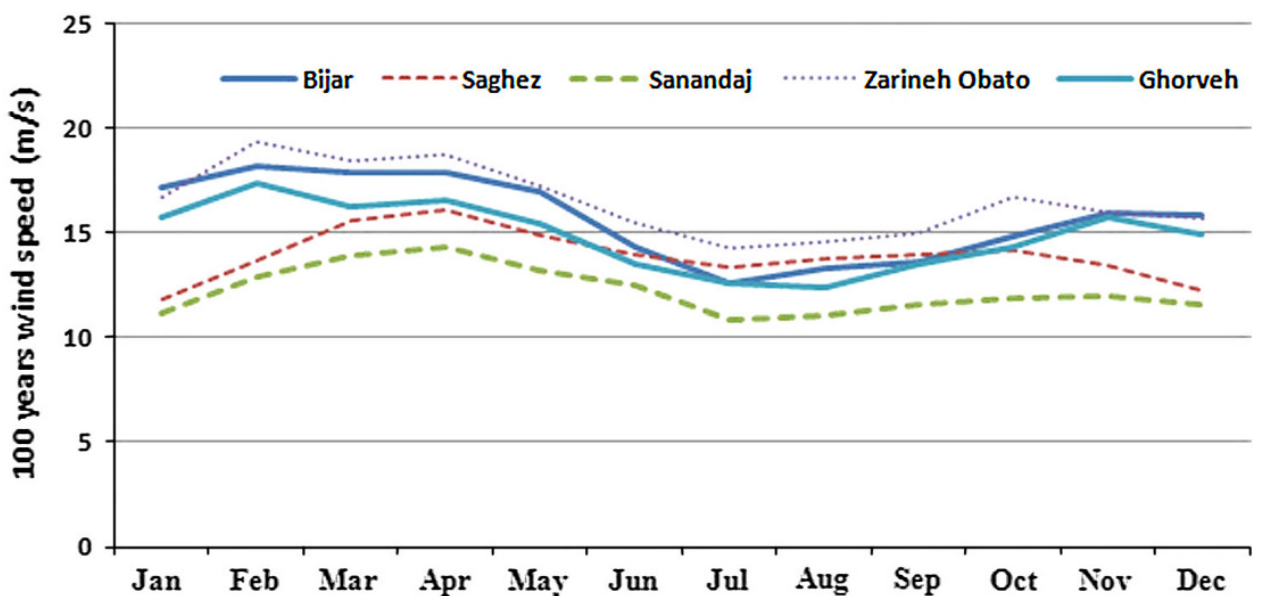

$422 \mathrm{kWh} / \mathrm{m}^{2} /$ month, which was observed in April in Bijar.

As it can be inferred from Table 8, high values of $E /$ $A$ were mainly observed at late winter and early spring, whereas small values belonged to hot months of the summer for the studied area.

Wind speed frequency analysis

According to $T$-year return period, wind speed was estimated from (20). For a given site, it was found that the wind speed increases as return period increases. Similar analyses were conducted for the monthly time scale. Figure 3 shows the wind speed corresponding to 100 years return period for the five selected sites.

As it can be seen from Fig. 3, the highest values at $T_{\mathrm{r}}=100$ years belonged to Zarineh Obato station, while the lowest value of 100 years wind speed belonged to
Sanandaj. In average, the rank of stations according to 100 years return period of wind speed is as: (1) Zarineh Obato, (2) Bijar, (3) Ghorveh, (4) Saghez and (5) Sanandaj.

For comparison purposes, relevant findings of some other researches for different locations are presented here. According to Köse [28], the wind power density at Kütahya, Turkey was about $36.6 \mathrm{~W} / \mathrm{m}^{2}$. Therefore, it can be concluded that all stations of Kurdistan province of Iran had high value of $P / A$ in comparison to Kütahya, Turkey. Köse found that the mean wind speed of Kütahya did not provide economical electricity production from the wind energy. This is not true for at least two stations of Kurdistan province of Iran. Mpholo et al. [30] studied wind power density at two sites, namely Masitise and Sani in the USA. They found that power density of both sites was given by 121.6 and $221.3 \mathrm{~W} / \mathrm{m}^{2}$. $\mathrm{Li}$ and $\mathrm{Li}$ [31] found that the average annual wind power density at Waterloo region of Canada was about $105 \mathrm{~W} / \mathrm{m}^{2}$. This value increased up to 
$180 \mathrm{~W} / \mathrm{m}^{2}$ in cold seasons. Akpinar and Akpinar [29] reported that the annual mean wind speed and mean power density of Maden-Elazig located in Turkey was $5.63 \mathrm{~m} / \mathrm{s}$ and $244.65 \mathrm{~W} / \mathrm{m}^{2}$.

In this study, we applied the wind data of five stations from different points of Kurdistan province of Iran. It was not possible to find more windy sites in this province. However, wind measurements were not available for such stations at this time.

\section{Conclusion}

By implementing the modern technology, it is possible to reduce fossil fuel consumption and solve serious atmospheric pollution problems. One of the most favorable options which decision makers should consider for providing the clean energy is wind turbine installation in suitable locations. There is no doubt that Iran has many locations which are suitable for wind energy production. In the present study, wind speed energy potential at five selected sites of Kurdistan province of Iran was investigated. The Weibull distribution was used for wind speed frequency analysis. The parameters of the mentioned distribution, i.e., $k$ and $c$ were estimated for all monthly and annual time series. Data were extended from 10 to 20 and $40 \mathrm{~m}$ heights above the ground surface using the power law. Four distinct characteristics of wind in relation to energy, i.e., the most probable wind speed, the wind speed having the maximum energy, wind power density and wind energy density were calculated for all sites in the monthly and annual time scale. The highest wind speed was experienced for the most of the sites in late winter and early spring. It was found that in the annual time scale the range of parameter $k(c)$ was between 0.78 (1.84) and 1.03 (4.37). In the monthly time scale, the range of parameter $k(c)$ was between 0.67 (1.23) and 1.45 (6.23). The most probable wind speed range varied from site to site and it was between $0.16 \mathrm{~m} / \mathrm{s}$ and $5.17 \mathrm{~m} / \mathrm{s}$. The range of wind speed which carries maximum energy was between 7.07 and $12.75 \mathrm{~m} / \mathrm{s}$ which was observed in late winter and early spring. The highest value of the wind power density at $10 \mathrm{~m}$ height was found to be $308 \mathrm{~W} / \mathrm{m}^{2}$. It was $424 \mathrm{~W} / \mathrm{m}^{2}$ at $20 \mathrm{~m}$ and $586 \mathrm{~W} / \mathrm{m}^{2}$ at $40 \mathrm{~m}$ height. Such level of power density may be adequate for wind generators, battery charging and water pumping. The highest value of $E /$ $A$ belonged to Bijar station having E/A at 10 and $20 \mathrm{~m}$ height equal to 222 and $305 \mathrm{kWh} / \mathrm{m}^{2} /$ month, respectively. In $40 \mathrm{~m}$, it was $422 \mathrm{Wh} / \mathrm{m}^{2} / \mathrm{month}$ which was observed in April at Bijar. Among the studied stations, Bijar and Zarineh Obato had a good situation for wind energy harnessing.
Open Access This article is distributed under the terms of the Creative Commons Attribution License which permits any use, distribution, and reproduction in any medium, provided the original author(s) and the source are credited.

\section{References}

1. Mostafaeipour, A., Abarghooei, H.: Harnessing wind energy at Manjil area located in north of Iran. J. Renew. Sustain. Energy Rev. 12(6), 1758-1766 (2008)

2. Celik, A.N: Energy output estimation for small-scale wind power generators using Weibull-representative wind data. J. Wind Eng. Ind. Aerodyn. 9, 693-707 (2003)

3. Mirhosseini, M., Sharifi, F., Sedaghat, A.: Assessing the wind potential locations in province of Semnan in Iran. J. Renew. Sustain. Energy Rev. 15, 449-459 (2011)

4. Mostafaeipour, A., Sedaghat, A., Dehghan-Niri, A.A., Kalantar, V.: Wind energy feasibility study for city of Shahrbabak in Iran. J. Renew. Sustain Energy Rev. 15, 2545-2556 (2011)

5. Weisser, D.: A wind energy analysis of Grenada: an estimation using the 'Weibull' density function. Renew. Energy 28, 1803-1812 (2003)

6. Rehman, S., Ahmad, A.: Assessment of wind energy potential for coastal locations of the Kingdom of Saudi Arabia. Energy 29, 1105-1115 (2004)

7. Katsoulis, B.D.: A survey on the assessment of wind energy potential in Greece. Theor. Appl. Climatol. 47, 51-63 (1993)

8. Bensoussan, A., Raphael Bertrand, P., Brouste, A.: Forecasting the energy produced by a windmill on a yearly basis. Stoch. Environ. Res. Risk Assess. 26, 1109-1122 (2012)

9. Ucar, A., Balo, F.: Investigation of wind energy potential in Kartalkaya-Balu, Turkey. Int. J. Green Energy 6, 401-412 (2009)

10. Ramachandra, T., Shruthi, B.V.: Wind energy potential mapping in Karnataka, India using GIS. Energy Convers. Manag. 46, 1561-1578 (2005)

11. Eskin, N., Artar, H., Tolun, S.: Wind energy potential of Gökçeada Island in Turkey. J. Renew. Sustain. Energy Rev. 12, 839-851 (2008)

12. Chellali, F., Khellaf, A., Belouchrani, A.: Application of timefrequency representation in the study of the cyclical behavior of wind speed in Algeria: wavelet transform. Stoch. Environ. Res. Risk Assess. 24, 1233-1239 (2010)

13. Rehman, S., Mahbub Alam, A.M., Meyer, J.P., Hadhrami, L.M.: Wind speed characteristics and resource assessment using Weibull parameters. Int. J. Green Energy 9, 800-814 (2012)

14. Ajayi, O.O., Fagbenle, R.O., Katende, J., Aasa, S.A., Okeniyi, J.O.: Wind profile characteristics and turbine performance analysis in Kano, north-western Nigeria. Int. J. Energy Environ. Eng. 4, 27 (2013). doi:10.1186/2251-6832-4-27

15. Rajabi, M.R., Modarres, R.: Extreme value frequency analysis of wind data from Isfahan, Iran. J. Wind Eng. Ind. Aerodyn. 96, 78-82 (2008)

16. Dinpashoh, Y., Fakheri-Fard, A., Moghadam, M., Jahanbakhsh, S., Mirnia, M.K.: Selection of variables for the purpose of regionalization of Iran's precipitation climate using multivariate methods. J. Hydrol. 297, 109-123 (2004)

17. Dinpashoh, Y.: Study of reference crop evapotranspiration in I.R. of Iran. Agric. Water Manag. 84, 123-129 (2006)

18. Xia, Y., Fabian, P., Stohl, A., Winterhalter, M.: Forest climatology: estimation of missing values for Bavaria, Germany. Agric. For. Meteorol. 94, 131-144 (1999)

19. Chang, T.J., Wu, Y.T., Hsu, H.Y., Chu, C.R., Liao, C.M.: Assessment of wind characteristics and wind turbines characteristics in Taiwan. Renew. Energy. 28, 851-871 (2003) 
20. Jacovides, C.P., Theophilou, C., Tymvios, F.S., Pashiardes, S.: Wind statistics for coastal stations in Cyprus. Theor. Appl. Climatol. 72, 259-263 (2002)

21. Seguro, J.V., Lambert, T.W.: Modern estimation of the parameters of the Weibull wind speed distribution for wind energy analysis. J. Wind Eng. Ind. Aerodyn. 85, 75-84 (2000)

22. Şahin, A.D.: Progress and recent trends in wind energy. Prog. Energy Consum. Sci. 30, 501-543 (2004)

23. Rao, A.R., Hamed, K.H.: Flood Frequency Analysis. CRC Press, Boca Raton (2000)

24. Rocha, P., Sousa, R., Andrade, C., Silva, M.: Comparison of seven numerical methods for determining Weibull parameters for wind energy generation in the northeast region of Brazil. Appl. Energy 89, 395-400 (2012)

25. Chow, V.T., Maidment, D.R., Mays, L.W.: Applied Hydrology. Mc-Graw Hill Publication, Maidenheach (1988)

26. Stedinger, J.R., Vogel, R.M., Foufoula-Georgiou, E.: Frequency analysis of extreme events. In: Maidment, D.R. (ed.) Handbook of Hydrology. McGraw Hill, Inc, Maidenheach (1997)
27. Shata, A.S., Hanitsch, R.: Electricity generation and wind potential assessment at Hurghada, Egypt. Renew. Energy 33, 141-148 (2008)

28. Köse, R.: An evaluation of wind energy potential as a power generation source in Kütahya, Turkey. Energy Convers. Manag. 45(11), 1631-1641 (2004)

29. Akpinar, E.K., Akpinar, S.: Determination of the wind energy potential for Maden-Elazig, Turkey. Energy Convers. Manag. 45(18), 2901-2914 (2004)

30. Mpholo, M., Mathaba, T., Letuma, M.: Wind profile assessment at Masitise and Sani in Lesotho for potential off-grid electricity generation. Energy Convers. Manag. 53, 118-127 (2012)

31. $\mathrm{Li}, \mathrm{M} ., \mathrm{Li}, \mathrm{X}$.: Investigation of wind characteristics and assessment of wind energy potential for Waterloo region, Canada. Energy Convers. Manag. 46(18), 3014-3033 (2005) 